\title{
Quantifying Total Environmental Impact of the Power Sector Using Input-Output Life Cycle Assessment: a case study for Thailand
}

\author{
Isara Muangthai ${ }^{1 *}$ and Sue J. Lin ${ }^{2}$ \\ ${ }^{1}$ Warash School of Maritime Science and Engineering, Solent University, East Park Terrace, Southampton, United Kingdom \\ ${ }^{2}$ Department of Environmental Engineering, National Cheng Kung University, Tainan 701, Taiwan
}

\begin{abstract}
The electricity generation is vital to industries and economic development in Thailand. In this study, the input-output life cycle assessment (IO-LCA) is applied to estimate the direct and indirect impacts from the power generation sector for the years 2005 and 2010. Based on the input-output analysis, more than $90 \%$ of the total environmental impact of Thailand's power sector involves ten relevant sectors. Results reveal that the most significant environmental damage was on natural resources followed by human health, climate change, and ecosystem quality. The most dominant environmental impacts were non-renewable energy, global warming and respiratory inorganic effects. Furthermore, the power sector, which accounts for $80 \%$ and $61 \%$ of total each impact in 2010 respectively, had a large direct impact on climate change and human health. On the contrary, the coal and lignite, and metal ore sectors contributed significantly to indirect impacts on ecosystem quality and resources. Regarding the results, some additional suggestions can be made to improve current policies in Thailand, including the implementation of green manufacturing in the iron and steel production, and installing control devices in all power plant units. Consequently, IO-LCA can be applied to other industries for assessing their total environmental impacts, and planning $\mathrm{CO}_{2}$ mitigation strategies.
\end{abstract}

\section{Introduction}

Electricity is a crucial factor in daily life, transportation, households, and all industrial sectors of a country. The electricity generation in Thailand significantly rose from 95,977 Gwh in 2000 to 184,350 Gwh in 2015. Of this total, thermal power contributed $73 \%$ of the total national grid generation in 2015, hydro power provided $7 \%$, and other alternative energy (solar, wind, biogas) supplied 20\% [1]. This reveals that Thailand's power generation still heavily depends on fossil fuel. In addition, $42 \%$ of total $\mathrm{CO}_{2}$ emissions from the energy consumption sector emitted from the power generation sector in 2015, while transportation, industry, agriculture and mining, and residential and commercial sectors contributed $30 \%, 19 \%, 6 \%$ and $3 \%$, respectively to total $\mathrm{CO}_{2}$ emissions [2]. The electricity generation sector plays an essential role in the country's economy, and environmental emissions; hence, it is important assess the potential environmental impacts caused by the electricity generation sector.

Life cycle assessment (LCA) is a tool to quantify the environmental impacts and resource utilization of a product's life cycle, process, or from cradle-to-grave [3]. There are two main approaches for conducting LCA: Process-based (P-LCA) and Input-Output life cycle assessment (IO-LCA). P-LCA is a comprehensive method that provides detailed results. However, P-LCA is a time consuming process, and it can have the problems of defining the system boundary and the circularity effect [4]. Conversely, IO-LCA is an integral method of input-output analysis (IOA) and LCA. IOA is an economic discipline that focus the inter-relationship between industries and households through producing and consuming commodities [5]. It has been used to extend the boundary of the product or process system in LCA; thereby, the economic-wide of embodied (direct and indirect) environmental burdens of a product or process can be traced. Moreover, the IO-LCA approach overcomes the disadvantage of P-LCA because the boundary includes transactions and emissions of all industry sectors. The result of IO-LCA can potentially be used as indicators in comparing products or sectors for strategic policy decision.

This study aims to evaluate the environmental impacts of Thailand's electricity for the years 2005 and 2010 by the IO-LCA. IO-LCA can be used to calculate the potential of environmental impacts from the electricity generation sector and other relevant sectors throughout the supply-chain of Thai's economy. This study focus not only on the direct environment impacts from the power generation process itself, but also the indirect impacts contributed from other related industries in the economy.

*Corresponding author: isara.muangthai@solent.ac.uk 


\section{Methodology}

\subsection{Input-Output Analysis (IOA)}

The IO model presents the financial flows of goods and services within an economy at a specific time [6]. A set of linear equation serves as the interdependency across a different sector of the economy. The standard representation of the IO model defines as follows [7] :

$$
\begin{gathered}
\sum_{j=1}^{n} x_{i j}+F_{i}=X_{i} \\
\sum_{j=1}^{n} a_{i j} X_{j}+F_{i}=X_{i} \\
a_{i j}=x_{i j} / X_{j}, \quad \mathrm{~A}=\left[a_{i j}\right]
\end{gathered}
$$

Where $X_{i}=$ the total output of every sectors;

$x_{i j}=$ the intermediate demand that represent amount of input from sector $i$ used by per unit of output sector $j$. for the output.

$F_{i}=$ the exogenous change in final demand

$\mathrm{A}=$ matrix of technical coefficient, calculated by dividing the industry-by-industry direct requirements of sectorial inputs by the sectorial production,

$a_{i j}=$ the dollar value of input required from sector $i$ to produce one dollar worth output of sector $j$

Eq. (2) can be rewritten as;

$$
\begin{gathered}
X=\mathrm{A} X+\mathrm{F} \\
X=(I-A)^{-1} F
\end{gathered}
$$

In this study, the domestic IO table was used to calculate the Leontief inverse matrix; therefore, $A$ table is replaced by $D$ table. Eq.(4) can be rewritten as

$$
X=(I-D)^{-1} F
$$

Where $X=$ the $(\mathrm{n} \times 1)$ vector of total economic outputs of the sectors,

$I=$ the identity matrix ( $\mathrm{n} \times \mathrm{n})$,

$D=$ the $\left(\begin{array}{lll}n & x & n\end{array}\right)$ inter-sectoral direct requirements (technical coefficients) matrix $(I-D)^{-1}=$ the domestic Leontief inverse matrix, representing the total amount of goods or service $i$ directly and indirectly needed to deliver a unit of final demand of good or service $j$.

$F=$ the (nx 1$)$ vector of exogenous change in final demand

\subsection{Input-Output Life Cycle Assessment (IO-LCA)}

Suppose that $R$ is a $k \times n$ matrix of environmental burden coefficients, where $\mathrm{R}_{\mathrm{kj}}$ is environmental burden $k$ (e.g. $\mathrm{CO}_{2}$ emissions) per dollar output of sector $j$. The economy-wide of total environmental burden associated with an exogenous demand can be calculated as follows, [8].

$$
\begin{aligned}
& Q=R X \\
& Q=R(I-D)^{-1} F
\end{aligned}
$$

Where $Q=$ the $(k \times n)$ vector of total (direct and indirect) environmental burden per monetary unit of output of each sector, total emission million US ${ }^{-1}$

$R=$ the $(k \times n)$ vector of direct environmental burden or pollutant emissions per monetary unit of output in each sector, direct emission million US\$ ${ }^{-1}$

$F=$ the $(\mathrm{n} \times 1)$ vector of exogenous change in final demand

\subsection{Life Cycle Impact Assessment}

The scope of IO-LCA in this paper is an economicoriented life cycle assessment of Thailand's electricity generation that focuses on one industry to another within the economy. The functional unit in this study was million US dollars of total output of each economic sector for baseyear 2010. This study uses SimaPro 7.3.3 software along with IMPACT 2002+ version 2.10. InputOutput USA database 2002 was chosen as environmental database inventory in the analysis. The Missing Inventory Estimation Tool (MIET) 3.0 version was employed to estimate the environmental emissions of US database through SimaPro 7.3.3.

The IMPACT 2002+ is a damage oriented impact assessment model, which combines the benefits from both mid-point and end-point methods. Asides from to the aggregation of midpoint/damage structure, the compara- tive assessment of human toxicity and ecotoxicity are estimated in IMPACT 2002+. The assessment of this model involves characterization, damage assessment, normalization, weighting and single score. The method- logy incorporates fourteen midpoint impact categories: human toxicity, respiratory effects, ionizing radiation, ozone layer depletion, photochemical oxidation, aquatic ecotoxicity, terrestrial ecotoxicity, aquatic acidification aquatic eutrophication, terrestrial acidification/nitrifi- cation, land occupation, global warming, non-renewable energy and mineral extraction [9]. All fourteen midpoints categories were linked to four damage categories which is human health, ecosystem quality, climate change, and resources. The respective share of each impact to overall damage of the considered category are analyzed through normalization. The details information of IMPACT $2002+$ method could be viewed in [9].

\subsection{Data consolidation}

National IO tables was compiled and published by The National Economic and Social Development Board (NESDB) of Thailand every five years. IO table in 2010 that launched in 2015 by NESDB is the latest IO table. This study employed two economic IO tables with a 180 sectors in years 2005, and $2010[10,11]$. The domestic IO table (D-table); excluding the import values, was adopted for the analysis to obtain more precise results of 
environmental impacts caused by industrial sectors in Thailand. Besides, the economic activity output were adjusted to the Gross Domestic Product (GDP) base year of 2010 in U.S. dollar prices to avoid fluctuating currency values. GDP data was obtained from World Bank Group [12], and the exchange rate of the Thai currency to the US dollar (\$) was adopted from The Bank of Thailand [13].

\section{Result and discussion}

The results herein shows ten most important sectors which totally accounts for more than $90 \%$ of the environmental impacts of the electricity generation sector in Thailand.

These sectors are given in Table 1

Table 1. Definition of ten important sectors

\begin{tabular}{|c|c|}
\hline Sector & Definition \\
\hline $\begin{array}{l}\text { Coal and } \\
\text { lignite }\end{array}$ & Mining of coal and lignite \\
\hline $\begin{array}{l}\text { Chemical } \\
\text { fertilizer }\end{array}$ & Extraction or mineral mining \\
\hline $\begin{array}{l}\text { Electricity } \\
\text { generation }\end{array}$ & $\begin{array}{l}\text { Electricity generation, transmission and } \\
\text { distribution of electric for sale to household, } \\
\text { industrial, commercial and public users }\end{array}$ \\
\hline $\begin{array}{c}\text { Insulated wire } \\
\text { and cable }\end{array}$ & The production of insulated wire and cable \\
\hline Metal ore & Extraction of metal ore such as tin, iron ore \\
\hline $\begin{array}{l}\text { Pipeline and } \\
\text { gas } \\
\text { distribution } \\
\end{array}$ & $\begin{array}{l}\text { Gas distribution such as liquid petroleum } \\
\text { gasoline }\end{array}$ \\
\hline $\begin{array}{c}\text { Petroleum } \\
\text { and natural } \\
\text { gas extraction }\end{array}$ & $\begin{array}{l}\text { The exploration activities for crude } \\
\text { petroleum and natural gas, the drilling and } \\
\text { operation of wells }\end{array}$ \\
\hline $\begin{array}{l}\text { Petroleum } \\
\text { refineries }\end{array}$ & Oil-processing refineries. \\
\hline Railways & Transportation of both passengers and cargo \\
\hline $\begin{array}{l}\text { Sanitary and } \\
\text { similar } \\
\text { services }\end{array}$ & $\begin{array}{l}\text { Operation of drainage systems and the } \\
\text { purification of water for consumption. }\end{array}$ \\
\hline
\end{tabular}

\subsection{Environmental Damage assessment}

The environmental damages from ten sectors relevant to Thailand's electricity generation sector in 2000, 2005, and 2010 are given in Table 2. Results show that electricity generation sector was the main contributor to human health damages. The damage increased from $1.21 \mathrm{E}+08$ in 2005 to $1.58 \mathrm{E}+08$ DALY in 2010 which accounts for $53.3 \%$ and $65 \%$ of each year's total human health damage, respectively. Moreover, the metal ore sector was the major contributor to ecotoxicity. The total damage slightly decreased from $8.31 \mathrm{E}+12 \mathrm{PDF}^{*} \mathrm{~m}^{2} * \mathrm{yr}$ in 2005 to $3.08 \mathrm{E}+12 \mathrm{PDF}^{*} \mathrm{~m}^{2} * \mathrm{yr}$ in 2010 which accounts for $62.5 \%$ and $54.6 \%$ to total ecotoxicity value in 2005 and 2010, respectively (Table 2). The metal ore sector is the primary source of iron and steel. According to the IO tables for 2005 and 2010, total demand of the iron and steel sector was 3,619,685 million USD, and $1,996,407$ million USD, respectively. This reveals that total demand for iron and steel declined 1.8 times from 2005 to 2010 . For this reason, high demand for iron and steel in 2005 directly affected the metal ore sector. Results also indicate that the electricity generation sector was the largest $\mathrm{CO}_{2}$ emission source contributing to climate change. The share of each year's total $\mathrm{CO}_{2}$ mission increased from $78.5 \%$ in 2005 to $80.3 \%$ in 2010 . For the resources, coal and lignite were major factors affecting resources and their share amounted to $70 \%$ and $15 \%$ of total resources in 2005 and 2010 , respectively (Table 2). Coal and lignite increased theirs shared in power generation from $17 \%$ in 2005 to $21 \%$ in 2010 of the total fuel mix [1]. Results from the IO table reveal that the coal and lignite sector furnished a huge support of 310,300 million USD to the electricity generation sector in 2005, whereas the support from these coal and lignite sector dramatically decreased to 30,309 million USD in 2010. That is, the electricity generation sector reduced the use of domestic coal and lignite approximately $30 \%$ from 2005 to 2010 . The electricity generation and petroleum and natural gas extraction sectors were two important contributors to the resources category.

Table 2. Environmental damages from ten sectors contributing to the Thai's electricity generation sector in 2005 and 2010

\begin{tabular}{|c|c|c|c|c|c|}
\hline Sector & Year & $\begin{array}{l}\text { Human } \\
\text { Health } \\
\text { (DALY) }\end{array}$ & $\begin{array}{l}\text { Ecotoxicity } \\
\left(\mathrm{PDF}^{*} \mathrm{~m}^{2 *} \mathrm{yr}\right)\end{array}$ & $\begin{array}{c}\text { Climate } \\
\text { change } \\
\left(\mathrm{kgCO}_{2} \text { eq }\right)\end{array}$ & $\begin{array}{c}\text { Resource } \\
\text { (MJ } \\
\text { primary) }\end{array}$ \\
\hline \multirow{2}{*}{$\begin{array}{l}\text { Electricity } \\
\text { generation }\end{array}$} & 2005 & $1.21 \mathrm{E}+08$ & $1.33 \mathrm{E}+12$ & $1.14 \mathrm{E}+14$ & $2.20 \mathrm{E}+15$ \\
\hline & 2010 & $1.64 \mathrm{E}+08$ & $1.67 \mathrm{E}+12$ & $1.44 \mathrm{E}+14$ & $2.76 \mathrm{E}+15$ \\
\hline \multirow{2}{*}{$\begin{array}{c}\text { Coal } \\
\text { and lignite }\end{array}$} & 2005 & $2.18 \mathrm{E}+07$ & $2.93 \mathrm{E}+12$ & $3.63 \mathrm{E}+13$ & $1.17 \mathrm{E}+16$ \\
\hline & 2010 & $2.03 \mathrm{E}+06$ & $2.73 \mathrm{E}+11$ & $3.38 \mathrm{E}+12$ & $1.09 \mathrm{E}+15$ \\
\hline \multirow{2}{*}{$\begin{array}{l}\text { Chemical } \\
\text { fertilizer }\end{array}$} & 2005 & $6.09 \mathrm{E}+06$ & $6.10 \mathrm{E}+10$ & $3.59 \mathrm{E}+12$ & $1.45 \mathrm{E}+14$ \\
\hline & 2010 & $4.11 \mathrm{E}+06$ & $4.12 \mathrm{E}+10$ & $2.42 \mathrm{E}+12$ & $9.77 \mathrm{E}+13$ \\
\hline $\begin{array}{l}\text { Petroleum } \\
\text { and }\end{array}$ & 2005 & $2.00 \mathrm{E}+07$ & $4.84 \mathrm{E}+10$ & $1.60 \mathrm{E}+12$ & $1.24 \mathrm{E}+15$ \\
\hline $\begin{array}{l}\text { natural gas } \\
\text { extraction }\end{array}$ & 2010 & $2.26 \mathrm{E}+07$ & $7.08 \mathrm{E}+10$ & $34 \mathrm{E}+12$ & $1.81 \mathrm{E}+15$ \\
\hline \multirow{2}{*}{$\begin{array}{l}\text { Petroleum } \\
\text { refineries }\end{array}$} & 2005 & $3.01 \mathrm{E}+06$ & $2.04 \mathrm{E}+10$ & $1.99 \mathrm{E}+12$ & $2.87 \mathrm{E}+14$ \\
\hline & 2010 & $3.24 \mathrm{E}+06$ & $2.19 \mathrm{E}+10$ & $2.15 \mathrm{E}+12$ & $3.09 \mathrm{E}+14$ \\
\hline \multirow{2}{*}{$\begin{array}{l}\text { Pipeline and } \\
\text { gas } \\
\text { distribution }\end{array}$} & 2005 & $3.54 \mathrm{E}+07$ & $1.46 \mathrm{E}+11$ & $1.44 \mathrm{E}+13$ & $6.39 \mathrm{E}+14$ \\
\hline & 2010 & $4.02 \mathrm{E}+07$ & $1.93 \mathrm{E}+11$ & $1.91 \mathrm{E}+13$ & $8.46 \mathrm{E}+14$ \\
\hline \multirow{2}{*}{ Metal ore } & 2005 & $9.46 \mathrm{E}+06$ & $8.31 \mathrm{E}+12$ & $6.79 \mathrm{E}+12$ & $1.64 \mathrm{E}+14$ \\
\hline & 2010 & $3.51 \mathrm{E}+06$ & $3.08 \mathrm{E}+12$ & $2.52 \mathrm{E}+12$ & $6.10 \mathrm{E}+13$ \\
\hline \multirow{2}{*}{$\begin{array}{l}\text { Insulated } \\
\text { wire and } \\
\text { cable }\end{array}$} & 2005 & $8.82 \mathrm{E}+05$ & $2.44 \mathrm{E}+11$ & $6.96 \mathrm{E}+11$ & $1.65 \mathrm{E}+13$ \\
\hline & 2010 & $3.08 \mathrm{E}+05$ & $8.49 \mathrm{E}+10$ & $2.43 \mathrm{E}+11$ & $5.77 \mathrm{E}+12$ \\
\hline \multirow{2}{*}{ Railways } & 2005 & $6.32 \mathrm{E}+06$ & $1.13 \mathrm{E}+10$ & $7.80 \mathrm{E}+11$ & $1.59 \mathrm{E}+13$ \\
\hline & 2010 & $7.94 \mathrm{E}+06$ & $1.42 \mathrm{E}+10$ & $9.80 \mathrm{E}+11$ & $2.00 \mathrm{E}+13$ \\
\hline \multirow{2}{*}{$\begin{array}{c}\text { Sanitary } \\
\text { and similar } \\
\text { services }\end{array}$} & 2005 & $3.78 \mathrm{E}+05$ & $8.63 \mathrm{E}+09$ & $3.29 \mathrm{E}+11$ & $7.15 \mathrm{E}+12$ \\
\hline & 2010 & $5.64 \mathrm{E}+05$ & $1.29 \mathrm{E}+10$ & $4.91 \mathrm{E}+11$ & $1.07 \mathrm{E}+13$ \\
\hline \multirow{2}{*}{$\begin{array}{c}\text { Total } \\
\text { impact }\end{array}$} & 2005 & $2.28 \mathrm{E}+08$ & $1.33 \mathrm{E}+13$ & $1.82 \mathrm{E}+14$ & $1.64 \mathrm{E}+16$ \\
\hline & 2010 & $2.52 \mathrm{E}+08$ & $5.64 \mathrm{E}+12$ & $1.79 \mathrm{E}+14$ & $7.05 \mathrm{E}+15$ \\
\hline
\end{tabular}




\subsection{Normalization of total environmental impacts}

Normalization of total environmental impacts from Thailand's electricity generation and other related sectors in 2005 and 2010 show in Figure 1. The most important environmental damage from normalization step was resources, followed by human health, climate change, and ecosystem quality. Resources impact dramatically decreased from $1.08 \mathrm{E}+11$ in 2005 to $4.64 \mathrm{E}+10$ in 2010 . he reduction of domestic coal and lignite consumption in the power sector was a reason for the decrease of resources from 2005 to 2010 . In addition, the impact value of resources decline in 2010 because the domestic natural gas shared in grid generation rose 5\% from 2005 to 2010 [1]. An increasing share of natural gas in the Thai's power generation in 2010 contributed a less effect to resources when compare with coal and lignite because natural gas is a cleaner fossil fuel,

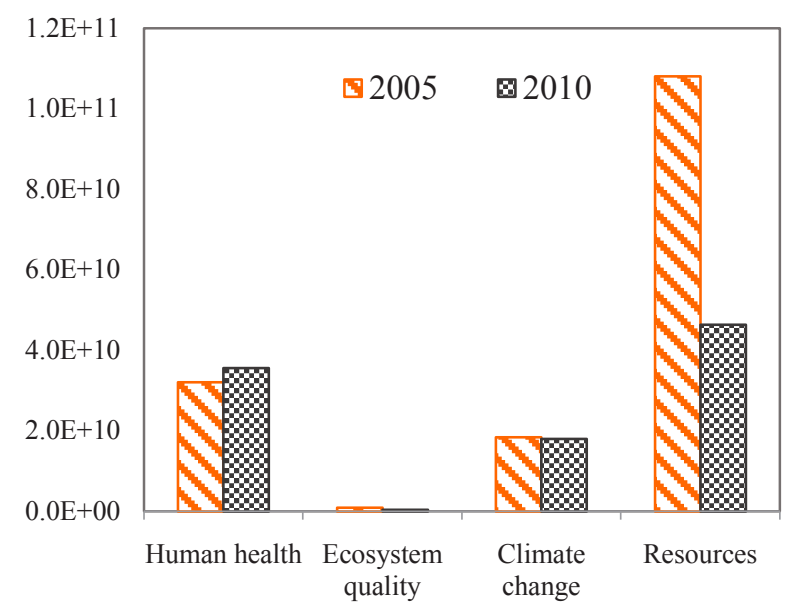

Fig. 1. Normalized environmental damage for 2005 and 2010

The damage value of human health increased from $3.21 \mathrm{E}+10$ DALY in 2005 to $3.56 \mathrm{E}+10$ DALY in 2010 , while the damage value of climate change slightly decreased from $1.84 \mathrm{E}+10$ in 2005 to $1.81 \mathrm{E}+10$ in 2010 (Fig 1). For the climate change normalized score, it is the same category as the midpoint category global warming. Results reveal that the electricity generation was the key contributor to global warming in two years. However, the ecosystem quality had the less effect to environmental damage because normalization factor for ecosystem quality is determined with some modification [9].

In order to understand the details of the impact categories, the normalized environmental impact per midpoint level categories for years 2005 and 2010 from 10 sectors are illustrated in Figure 2. Results show that non-renewable energy, global warming and respiratory inorganics effects were three dominant environmental impacts. The normalized value of global warming and respiratory inorganics also increased from 2005 to 2010. On the other hand, the normalized value of nonrenewable energy decreased from 2005 to 2010. This result accordance with previous result of normalization of total environmental impact, that is decreasing of nonrenewable energy impact from 2005 to 2010.

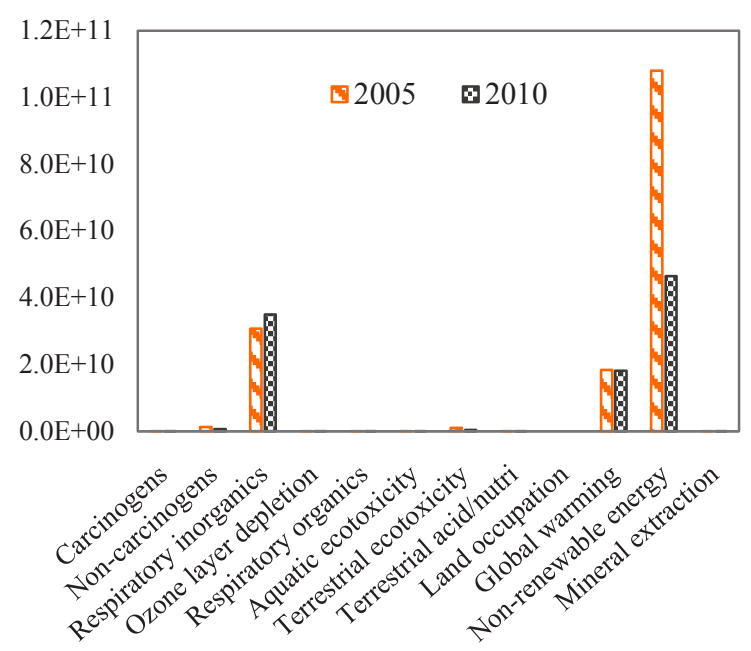

Fig. 2. Normalization of total environmental impacts for 2005 and 2010

\subsection{Direct and indirect environmental impacts}

Table 3. The percentage of direct and indirect environmental impact of Thailand's electricity generation sector

\begin{tabular}{cccccc}
\hline \multirow{2}{*}{ Year } & $\begin{array}{c}\text { Nature of } \\
\text { impact }\end{array}$ & $\begin{array}{c}\text { Human } \\
\text { health }\end{array}$ & $\begin{array}{c}\text { Ecosystem } \\
\text { quality }\end{array}$ & $\begin{array}{c}\text { Climate } \\
\text { change }\end{array}$ & Resources \\
\hline \multirow{2}{*}{2005} & Direct & $53 \%$ & $10 \%$ & $63 \%$ & $13 \%$ \\
& Indirect & $47 \%$ & $90 \%$ & $37 \%$ & $87 \%$ \\
\hline \multirow{2}{*}{2010} & Direct & $61 \%$ & $30 \%$ & $80 \%$ & $39 \%$ \\
& Indirect & $39 \%$ & $70 \%$ & $20 \%$ & $61 \%$ \\
\hline
\end{tabular}

The proportion of direct and indirect impacts for each damage category are given in Table 3. Results indicate that the climate change category had the largest direct effects over other impacts, and its proportion accounts for $63 \%$, and $80 \%$ in 2005 , and 2010 , respectively. In addition, the estimated carbon dioxide $\left(\mathrm{CO}_{2}\right)$ from Thai's power sector gradually increased every year, especially in 2010 (Fig. 3) [1,2].

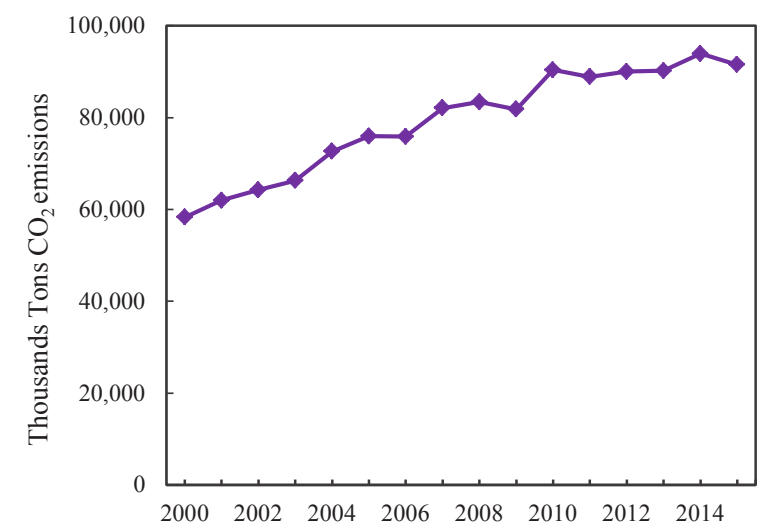

Fig. 3. $\mathrm{CO}_{2}$ emissions from the Thai's power sector 2000-2015

$\mathrm{CO}_{2}$ emission from the power sector increased along 2000 to 2015 with average growth $3.3 \%$ per year due to the increasing of electricity consumption and population. However, the direct impact on human health from the 
electricity generation sector itself increased from 53\% in 2005 to $61 \%$ in 2010 . On the other hand, ecosystem quality and resources mainly came from indirect effects. The percentage of ecosystem quality from an indirect effect was $90 \%$ in 2005, and 70\% in 2010 (Table 3). The metal ore sector is considered as one of the indirect sources that contributes to ecosystem quality. Moreover, the indirect proportion of resources were higher than the direct proportion because the power sector needs to reply on fossil fuel from upstream sectors like the coal and lignite and petroleum and natural gas extraction sectors. Therefore, these sectors emerge as significant sources affecting resources.

\section{Conclusion}

This study utilized IO-LCA to explore the direct and indirect environmental impacts of Thailand's electricity generation sector. Regarding the damage assessment results, the coal and lignite sector caused major damages in 2005. The normalization results shows that the most crucial environmental damages were resources, followed by human health, climate change, and ecosystem quality. The reduction of domestic coal and lignite in the fuel mix of grid generation in 2010 resulted in a dramatic decreased of resources from 2005 to 2010. In addition, non-renewable energy, global warming, and respiratory inorganic effects were the most dominant normalized environmental impacts from the electricity generation and its related sectors. Additionally, results of the direct and indirect effects reveal that the electricity generation sector had the highest direct impact on climate change because of it was the major contributor to $\mathrm{CO}_{2}$ emissions. In contrast, other relevant sectors played significant roles regarding ecosystem quality and resources. Since the electricity generation sector links with various industrial sectors, there could be an underestimation of indirect impacts if the other related sector are excluded from the calculation.

In summary, IO-LCA is a useful method that estimate the direct and indirect environmental impacts from the power sector which includes the indirect impacts from the associated sectors in demand-supply system. The main function of Sima Pro software offer the calculation of environmental impacts. The methodology used herein can be applied to other important industries to estimate the embodied environmental impacts, to plan mitigation strategies to lowering $\mathrm{CO}_{2}$ emissions and other environmental emissions.

\section{Recommendation}

The Thai government needs to pay attention to the emissions from both direct source from electricity generation and indirect sources such as coal and lignite, petroleum and natural gas extraction and metal ore sectors. Regarding the ecosystem quality, the metal ore sector was the main contributor to ecotoxicity. The iron and steel sector is a major sector that consumes metal ores. The government should adopt a more sustainable development policy for the iron and steel industry. Green manufacturing should focus on investigating energy saving techniques and reducing $\mathrm{CO}_{2}$ emission from producing steel. Recycling of steel scrap would help to reduce the need for extracting the metal ore. Regarding the result, the electricity generation sector had a tremendous affected global warming, non-renewable energy and respiratory inorganics. A control device such as flue-gas desulfurization and fabrics filter collectors should be installed in all power plant units, and there should regular monitoring the efficiency of the devices. Furthermore, the government of Thailand and other relevant agencies should focus not only the energyrelated $\mathrm{CO}_{2}$ emission from the power sector, but also the concern of human health from its pollution.

\section{Reference}

1. Department of Alternative Energy Development and Efficiency, Thailand Alternative Energy 2015. Ministry of Energy, Bangkok, Thailand. pp. 28-29. (2015a).

2. Department of Alternative Energy Development and Efficiency. Energy Balance of Thailand 2015. Ministry of Energy, Bangkok, Thailand. pp. 2223,48, 60. (2015b).

3. ISO 14040 International Standard, Environmental Management-Life Cycle Assessment-Principles and Framework. International Organization for Standardization, Geneva, Switzerland. (2006)

4. CT. Hendrickson, LB. Lave, HS. Matthews. Environ- mental Life Cycle Assessment of Goods and Services: An Input-Output Approach. Resources for the Future, Washington, DC. (2006)

5. G. Finnveden, M. Z. Hauschild, T. Ekvall, J., Guinée, R. Heijungs, S. Hellweg, A. Koehler, D. Pennington, and S. Suh. Recent Developments in Life Cycle Assessment.J Environ Manag. 91, 1-21 (2009).

6. RE.Miller, PD. Blair. Input-Output Analysis: Foundations and Extensions. Cambridge University Press, New York. (2009).

7. SJ. Lin, YF. Chang. Linkage Effects and Environmental Impacts from Oil Consumption Industries in Taiwan. J Environ Manag. 49, 393-411 (1997).

8. CH. Liu, SJ. Lin, C. Lewis. Environmental Impacts of Electricity Sector in Taiwan by Using InputOutput Life Cycle Assessment: The Role of Carbon Dioxide Emissions. Aerosol Air Qual Res. 12, 733744. (2012)

9. Jolliet, O., Margni, M., Charles, R., Humbert, S., Payet, J., Rebitzer, G. and Rosenbaum, R. Impact 2002+: A New Life Cycle Impact Assessment Methodology. The International Journal of Life Cycle Assessment, 8, 324-330. (2003).

10. National Economic and Social Development Board. Input-Output Table of Thailand 2005. Retrieved 20 
July 2014,from Office of the National Economic and Social Development Board (2005).

11. National Economic and Social Development Board. Input-Output Table of Thailand 2010. Retrieved 24 October 2015, from Office of the National Economic and Social Development Board (2010).
12. World Bank Group.World Development Indicators. Last access 5 December, 2015 (2015).

13. Bank of Thailand Rates of Exchange of Commercial Bankshttps://www.bot.or.th/English/Statistics/ FinancialMarkets/Pages/StatExchangeRate.aspx. Accessed 12 June 2016 (2016). 